\title{
REVIEW OF INTERNATIONAL SCIENTIFIC CONFERENCE "ACCOUNTING AND FINANCE: INNOVATIVE SOLUTIONS FOR SUSTAINABLE BIOECONOMY AND RURAL DEVELOPMENT"
}

\begin{tabular}{|c|c|}
\hline Reviewer: & Assoc. prof. dr. Jurgita Baranauskienè \\
\hline JEL classification: & Y80 \\
\hline \multirow[t]{3}{*}{ Title of the International Conference: } & ACCOUNTING AND FINANCE: INNOVATIVE \\
\hline & SUSTAINABLE \\
\hline & BIOECONOMY AND RURAL DEVELOPMENT \\
\hline Organiser(s): & Vytautas Magnus University Agriculture Academy, Lithuania \\
\hline Date: & $19-20^{\text {th }}$ November, 2020 \\
\hline Venue: & $\begin{array}{l}\text { Vytautas Magnus University Agriculture Academy, Studentų st. 11, } \\
\text { Akademija, Kaunas distr. LT-53361, Lithuania }\end{array}$ \\
\hline Language: & English and Lithuanian \\
\hline Contact person(s): & $\begin{array}{l}\text { Aurelija Markelyte } \\
\text { Studentu str. 11, Akademija, } \\
\text { LT-53361 Kaunas distr., } \\
\text { Lithuania }\end{array}$ \\
\hline E-mail: & afk@vdu.lt \\
\hline Conference website: & https://afk.vdu.lt/en/common-information/ \\
\hline Conference material: & $\begin{array}{l}\text { Scientific articles can be published in the open access scientific } \\
\text { journal "Science and Studies of Accounting and Finance: Problems } \\
\text { and Perspectives" (e-ISSN 2351-5597) indexed in international } \\
\text { databases: Business Source Corporate Plus, ERIH PLUS, DOAJ }\end{array}$ \\
\hline
\end{tabular}

International scientific conference "Accounting and Finance: Innovative Solutions for Sustainable Bioeconomy and Rural Development" is organized by Vytautas Magnus University Agriculture Academy and partly sponsored by Lithuanian Rural Network.

This conference is organized every second year and has a deep traditions International scientific conference "Accounting and Finance: Innovative Solutions for Sustainable Bioeconomy and Rural Development" is the conference is being held for the 12th time.

The Faculty of Bioeconomy development plays a key role in the organization of the conference. Faculty of Bioeconomy Development is the first in Lithuania in development and research in the science of bioeconomy, have the leading researchers dedicated to development of strategic solutions for business development and policy making in bioeconomy, prepare highly qualified, professional experts in policy making for agriculture and regional development, holding sufficient competence to create own business, develop close relations with bioeconomy business leaders and authorities.

The last conferences were attended by scientists, politicians, businessmen from many countries of the world. It should be noted that the interest of researchers, business and government in the participation of conference is increasing. It allows scientific ideas and research results to be disseminated and develop networks between science, business and government.

Copyright (C) 2020. Published by Vytautas Magnus University. This is an open access article distributed under the terms of the Creative Commons Attribution Non-Commercial 4.0 (CC BY-NC 4.0) license, which permits unrestricted use, distribution, and reproduction in any medium provided the original author and source are credited. The material cannot be used for commercial purposes. 
International scientific conference "Accounting and Finance: Innovative Solutions for Sustainable Bioeconomy and Rural Development" is designed to discuss research ideas in area of accounting and finance and share research results that are relevant to business and public organisations operating in bioeconomy sector and rural areas. Our goal is to identify innovative sustainable development and appropriate solutions, in order to increase business sustainability bioeconomy and efficiency, to promote partnership of small and medium-sized enterprises and public sector.

One of the key words of international scientific conference "Accounting and Finance: Innovative Solutions for Sustainable Bioeconomy and Rural Development" is "Sustainable Bioeconomy". Bioeconomy is one of the priority research areas at Vytautas Magnus University. This is related to the growing importance of the bioeconomy not only in Lithuania, the European Union and even in the world.

Bioeconomy covers sustainable production of renewable biological resources and processing of the resources and waste into value added products, such as food, feed, products produced using raw materials with biological origin, and bioenergy. The bioeconomy sectors are targeted towards a more innovation-based, low-carbon economy, providing biological diversity and environmental protection. Bioeconomy sectors creating added value for the EU: agriculture, forestry, Fishing and agriculture; food, beverages and other agro-manufacturing; bio-based textiles; wood products and furniture; paper; bio-based chemicals and pharmaceuticals, plastics and rubber; liquid biofuels.

The number of different sectors and policy domains, which govern the bioeconomy, are as heterogeneous as the different bioeconomy activities. Strategies that aim at the strengthening of the bioeconomy at regional, national or European levels affect people, the economy and the environment - within the boundaries of the respective area and beyond. New markets, novel cash crops and changes in land tenure may lead to environmental benefits and socio-economic opportunities, for instance by revitalising rural and coastal areas by providing new income sources, thereby preventing rural exodus. At the same time, challenges might occur related with innovative decisions for financial management, accounting, business taxation, financial risks, etc.

The aim of international scientific conference "Accounting and Finance: Innovative Solutions for Sustainable Bioeconomy and Rural Development" is strengthening the cooperation of scientists and sharing the knowledge in the field of accounting and finance in the context of bioeconomy and rural development, enabling scientists to discuss about the results of research at an international level. The main focus is on the following topics:

Innovative solutions for accounting and audit in business and public organisations operating in bioeconomy sector and rural areas (financial accounting; management accounting; social accounting; environmental accounting; accounting information systems; business taxation; audit quality, effectiveness and ethics, etc.).

- $\quad$ Business finance and financial management for sustainable bioeconomy and rural development (financial analysis, planning and valuation; financial econometrics; investment diversification; financial markets; financial behaviour; climate finance; green financing, etc.).

Public finance for sustainable bioeconomy and rural development (financial support; financial instruments; models of public finance management, financial risk management, etc.).

Conference participants will present their research and financial innovations disclosed in bioeconomy sectors. Digital technologies in finance and accounting such as artificial intelligence, robotics, blockchain, high performance computing and $5 \mathrm{G}$ have the potential to increase bioeconomy sectors efficiency and improve production, and also to contribute to make bioeconomy sector more sustainable from an economic, social and environmental point of 
view. The lack of skills is the challenge to increased investments in digital applications. In many cases, new competencies, research, innovation and discussions are still required to develop financial solutions.

It is a tradition organize the discussion forum and award the possibility for different sectors participants to express their attitudes. This $12^{\text {th }}$ international conference forum is dedicated for discussion "Future of accounting and finance: what competencies do we need to invest already?" The purpose of the forum is to discuss about the changes in the competencies of accounting and finance specialist in the context of technological innovation. Forum discussion keynote speakers are business representatives, representatives of higher education institutions, representatives of relevant business associations. Topics of forum discussion:

- Changes in the Competences of Accounting and Financial Specialists in the Context of Robotization and Digitalization (changes in the accounting process and professional, personal and social competences)

- Changes in Accounting and Financial Studies in the Context of Technological Innovation (changes in the partnership between research institutions and business; study subjects and topics; teaching and learning methods)

International scientific conference "Accounting and Finance: Innovative Solutions for Sustainable Bioeconomy and Rural Development" has already become a biannual tradition to meet colleagues from Lithuania and other counties and different sectors: scientists, practitioners, policy makers, private sector actors, NGOs. All the participants will be awarded the possibility to express their attitudes towards the scientific issues related to accounting and finance, especially in the focus of bioeconomy challenges and rural development. 